UDC 502.74:631.55:346.12

(C) 2017

O. Furdychko, Academician of the NAAS, Doctor of Agricultural Sciences

V. Novytskyi, Candidate of Agricultural Sciences

Institute of Agroecology and Nature Management, National Academy of

Sciences of Ukraine

\title{
ECOLOGICAL ASPECTS OF PROTECTION OF FAUNA DURING FIELD WORK
}

The purpose. To analyze ecological-and-legal aspects of protection of fauna in agricultural landscapes of Ukraine and abroad and to develop normative instruments preventing destruction of animals and auks at mechanized agrotechnical operations. Methods. They used traditional for forest-steppe zone machines and techniques of producing forages; monitoring of field fauna was carried out visually and fractionally by means of photoregistration; mathematicaland-statistical analysis of results of researches were spent with the use of conventional procedures and software SPSS Statistics 17.0. Results. During approbation of the developed normative instruments of avoidance of destruction of animals and auks remainance of background kinds of grey hare and grey ptarmigan grew up to $35-40 \%$. Conclusions. Observance in production conditions of the offered «Demands on avoidance of destruction of objects of fauna at mechanized agrotechnical operations» has stipulated essential lowering of destruction of experimental field fauna and has not led to aggravation of resources-and-economic indexes of economic activities of farms.

Key words: protection of fauna, agrotechnical operations, ecological-and-legal instruments, grey hare, grey ptarmigan.

Formulation of the problem. The permanent decrease in the number of field fauna has gradually turned into a conservation problem of pan-European scale over the last decades. In particular, the crisis of species bioindicators of ecological state of local agricultural landscapes [1, 2] - brown hare and gray partridge, ranging from the 90s of last century, actively discussed by scientists in Western Europe, while in the post-Soviet countries recently given this issue enough attention. Compared with the developed countries of the European Union, where among the main negative factors scholars have identified a total transformation of man-made landscapes with intensive agriculture and various constraints in managing populations of predators in Ukraine, except for the presence of these problems, it is worth noting a number of other - mainly due to the imperfection of the regulatory legal provision of hunting and agricultural production in general $[3,4]$. 
Analysis of recent research and publications. According to domestic scientists [5, 6], the population of field fauna in our state suffer losses of up to $50 \%$ or more from annual growth only during mechanized agricultural works. In particular, specialized studies found [6] - 43\% of the offspring gray rabbit dies during harvesting green mass and hay harvest, $15.3 \%$ is a result of chemicals lands and only $12.4 \%$ - as a result of illegal mining. In general, factors of direct limiting influence of agricultural genesis made up $62 \%$ of all causes of death of animals. The researchers $[5,6]$ also observed that most mortality occurs fauna field representatives during the first slope hay and harvesting of perennial forage grasses that all natural areas of the state coincides with periods of mass offspring. At this time, $45-65 \%$ of oviposition birds of the earth are destroyed, in particular a number of parietal (Galliformes). We did not find information about losses caused to populations other than hunted fauna, however, it is obviously even more disappointing, given the considerable variety of the latter.

As a result, today, in most regions of Ukraine, the current density of brown hare and chickpeas are 6-8 times lower than in neighboring Poland, Slovakia, Hungary, etc. - in the states with no better natural and climatic conditions for the existence of these species. Such unjustified environmental damage for the XXI century are particularly due to unregulated appropriate domestic agricultural production, have not been typical for the EU and contrary to the modern state environmental policy and a number of international conventions and commitments undertaken by Ukraine.

Among these, it should be noted that over the past two decades there has been intense progress in the industrialization of the domestic plant growing sector, which is expressed, first of all, by a significant improvement in the technical characteristics of imported agricultural machinery. For example, the width of the working grab with aggregates and the speed of the working movement of modern tillage, feed and grain harvesting equipment increased from the traditional 3-5 $\mathrm{m}$ to 10-12 $\mathrm{m}$ and 3,5-5 up to $28 \mathrm{~km} / \mathrm{h}$. Both factors, according to foreign scientists [7, 8], nowadays are dominant in the growing mortality of wild animals due to the restriction of the ability to leave the danger zone in time, but in no way regulated in Ukraine by environmental regulatory acts.

In this key, it is important to mention two potentially disruptive factors, which, unlike the previous one, do not require resource overconsumption. These are tactical and organizational limitations in the fieldwork in relation to agrotypographic features of the area, which exist at the legislative, regulatory and instructional levels in most EU countries and the post-Soviet area [4, 7, 9, 10], while in our country such requirements were developed Even at the time of the USSR [6, 11, 12] and with independence [13, 14], however, they are still 
exclusively recommendatory in nature. Another aspect is not caused by the urgent economic necessity of lining agricultural machinery into a tight diagonal-stepped series for the execution of similar operations, which increases the width of continuous capture of the area during its simultaneous cultivation.

Fundamental reasons for the above described situation, we see in the following components:

$>$ lack of state policy aimed at creating a legal field for the formation of an optimal phytocoenic structure of agro-landscapes, taking into account not only agricultural but also nature conservation and recreational purposes;

$>$ inadequate legislative protection of the animal world in general;

$>$ weak mechanisms of state control over the fulfillment of existing requirements.

Regarding the imperfection of the normative provision for the protection of the harmless fauna of agro-landscapes, it is necessary to focus attention on Article 40 "Prevention of the death of animals during the production processes and the exploitation of vehicles" of the Law of Ukraine "On the Fauna", which obliges enterprises, institutions, organizations and citizens to take measures for preventing the death of animals during the implementation of production processes, including in the process of agricultural work. In spite of this, in Ukraine, to date, no targeted by-laws have been created that would regulate individual methods and means of agricultural production in accordance with the said article. It is noteworthy that such regulations to the relevant articles of similar laws have been in force in most CIS countries since the mid-late 90's (for example, the RF Government Decree № 997 of 13.08.1996). In various modifications of such documents are regulated in particular tactical schemes of movement of technology, technology, special equipment for agricultural aggregates, etc., which exclude the possibility of massive death of wild animals. In developed EU countries - France, Germany and the UK at various levels of government and local authorities, these regulations are even greater restrictions on the activities of farmers where particularly regulated minimum cutting height of some crops during periods of mass reproduction of fauna, the maximum speed and width of the working machinery, etc.

Thus, the necessity of developing such normative legal acts in our state is dictated by the current depressive state of faunal complexes of local agrolandscapes and the lack of accentuated declaration in the domestic basic laws and by-laws of the regulatory acts prescribed, mandatory for implementation, methods and means of preventing the death of harmless field fauna in The process of economic and other activities, in particular during the implementation of mechanized agricultural works. 
Due to the aforementioned reasons, we, in agreement with the Ministry of environment and Natural Resources of Ukraine and the State Agency of Forest Resources of Ukraine, drafted by order approving the "Requirements to prevent the death of animals during mechanized farming operations' ( further Requirements), taking into account international best practices, and its own domestic scientific developments in this area, based on mutually adaptation and harmonization of their content to modern agricultural production conditions and environmental priorities of the state.

The purpose of research - to analyze environmental and legal aspects of agricultural landscapes fauna in Ukraine and abroad and to develop regulatory tools prevent the death of animals during the execution of mechanized farming operations.

Materials and methods of research. Approval of the project Requirements were carried out during 2015-2017 on arable lands and in natural meadows of PJSC "Bezborodivsk AVEC" in Cherkassy region. This was highlighted by three research areas under crops of agrofitotsenotyc groups and assigned them unchanged workers and farm machinery to perform the most dangerous for fauna field [5-7, 11] farming operations: 1). Harvesting alfalfa green mass (the first gathering of the year, living surface area - $50 \mathrm{ha}$ ) - combine CLAAS JAGUAR 850 with frontal placement reaper, working width - $3.0 \mathrm{~m}$; 2). Mowing of mushy grasses on hay (first slope in a year, area of a plot - 105 hectares) - mounted mowing unit KPN-2.1, aggregated on the basis of tractor MTZ-82. Working width of capture - $2.1 \mathrm{~m}$; 3). Broken winter wheat (area of the site - 80 hectares) - JOHN DEERE - 9880 STS harvester. The working width of the hoist is $6,10 \mathrm{~m}$.

Investigated objects of the animal world: gray partridge (Perdix perdix L.) sedentary aboriginal species, background in agricultural lands of all natural zones of the state; brown hare (Lepus europaeus Pall.) - a sedentary aboriginal species inhabited by agrolandscapes, open and semi-enclosed natural lands of Ukraine. The monitoring of wildlife objects was carried out visually and, partly, with the help of photoregistration.

In 2015, harvesting was carried out in a traditional way. During the two following field seasons 2016-2017, agrotechnical work on the experimental sites was carried out in accordance with the requirements of the project. Mathematical and statistical processing of the results of the research was carried out according to generally accepted methods $[15,16]$ on the PC using the software SPSS Statistics 17.0.

Research results. Key requirements of the project and the results of their approbation are given below: 
1. It is prohibited to use tactical schemes for the implementation of mechanized agrotechnical works during harvesting and harvesting in natural and artificial meadows, crops of fodder grasses and cereals, which provide for the movement of agricultural machinery or translational shuttle traffic, from two or more sides of the cultured circuit, In the direction from the periphery to the center of the processed contour.

2. During the implementation of mechanized agrotechnical works on harvesting of forages and harvesting in natural and artificial meadows, crops of forage grasses and grain crops, any preliminary cultivation, including fire-fighting, perimeter of the cultivated circuit, shall not be allowed later than 2 days prior to The beginning of implementation of the above basic works.

3. During harvesting in natural and artificial meadows, crops of forage grasses and cereals, the following tactical schemes for the implementation of mechanized agrotechnical works are required, which include: a) translational shuttle movement of agricultural machinery only on one side of the processed circuit in the direction opposite, which does not bordering with the objects of infrastructure (if any); b) translational shuttle or circular motion of agricultural machinery from the center of the cultured circuit in the direction to its periphery; c) other types of movement of agricultural machinery, are not limited by these Requirements or current legislation.

4. It is required to observe the minimum distance between separate units of agricultural machinery, which is lined up in the diagonal-step series in the implementation of the same type of mechanized agricultural works: $200 \mathrm{~m}$ - during the light period of the day; $300 \mathrm{~m}$ - at night time. The results obtained show that without complying with the requirements of the above provisions, the proportion of conservation of young rabbit gray in experimental areas was: $40.0 \%$ - in the first year of harvesting of green alfalfa; $42,1 \%$ - at the first year of the mowing of grass; $75.0 \%$ - for the harvest of spike crops (Table.1).

1.Influence of agrotechnical works on the local tsenopopulation of brown hare,

$$
\mathrm{M} \pm \mathrm{m}
$$

\begin{tabular}{|l|c|c|c|}
\hline \multirow{2}{*}{\multicolumn{1}{|c|}{ Type of agrotechnical works }} & \multicolumn{3}{|c|}{ Number of animals 1} \\
\cline { 2 - 4 } & 2015 & 2016 & 2017 \\
\hline Preparation of green alfalfa mass & $6 / 9$ & $12 / 4$ & $14 / 5$ \\
\hline Mowing grass & $8 / 11$ & $6 / 2$ & $10 / 3$ \\
\hline Harvesting grain & $3 / 1$ & $3 / 0$ & $2 / 0$ \\
\hline \multicolumn{1}{|c|}{ Together } & $17 / 21$ & $21 / 6$ & $26 / 8$ \\
\hline
\end{tabular}




\begin{tabular}{|c|c|c|c|}
\hline On the average, & $\begin{array}{c}5,7 \pm 1,45 / \\
7,0 \pm 3,06\end{array}$ & $\begin{array}{c}7,0 \pm 2,65 / \\
2,0 \pm 1,15\end{array}$ & $\begin{array}{c}8,7 \pm 3,53 / \\
2,7 \pm 1,45\end{array}$ \\
\hline
\end{tabular}

${ }^{1}$ Animals which: left the area / perished

In the following years, the following results were obtained for the conservation of animals, according to the above types of work, respectively: 75.0\%; 75.0\%; 100\% (2016) and 73.7\%; 76.9\%; 100\% (2017).

Consequently, for observance of the Requirement for cutting the green mass of seed and meadow grasses, the conservation of the brown hare grew equally by $32.9-35.0 \%$. The objective increase in the safety of animals during threshing of spike crops is difficult to judge at this time because of the very low rate of their occurrence and plural behavior in the studied stanzas (pictures 1, 2).
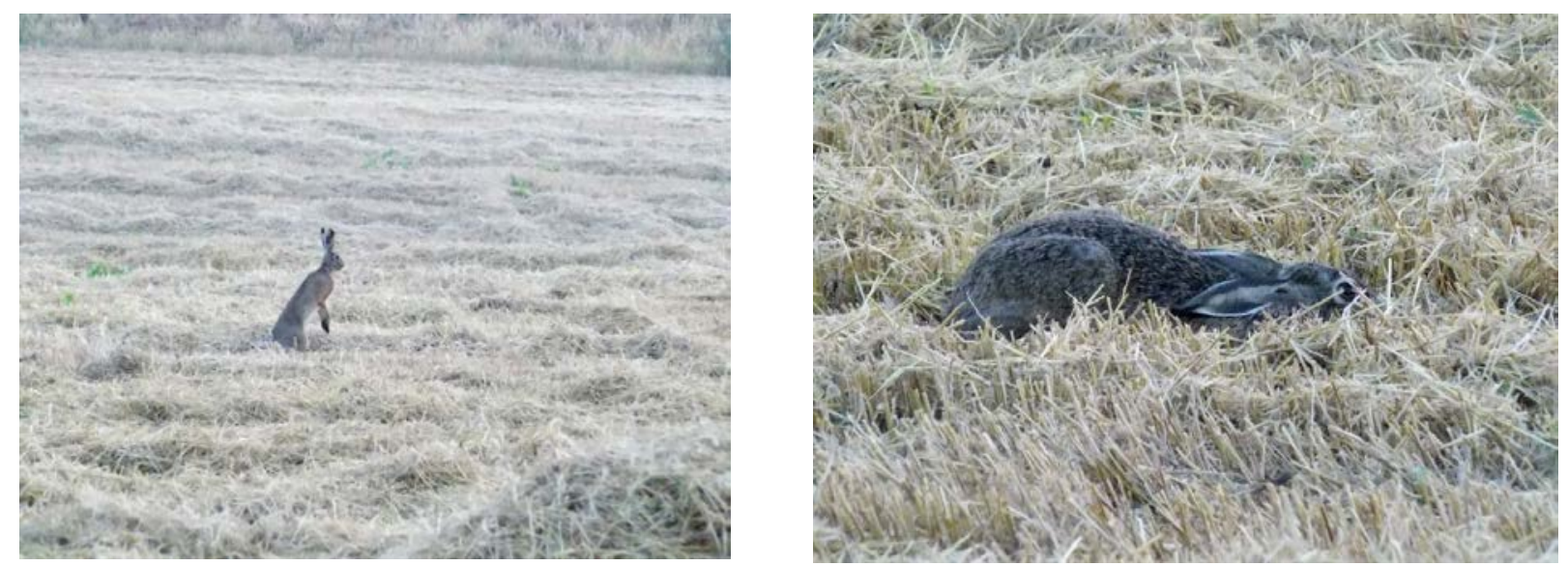

Pictures 1, 2. The brown hare. Individuals are captured within a single field path with a different behavioral response to the approach of an agricultural machine (C) V. Novitsky, Cherkasy oblast, 2015. On the left - an animal that did not allow a critical tractor to approach, leaving the area under cultivation on the right. On the right hand, stable reflex shaking, risked getting under the wrapping unit).

During the 2015 season, the share of the storage of gray patridge (nestudevel) in the studied areas was: $60.0 \%$ - at the first year of harvesting of green alfalfa mass; $55,6 \%$ - at the first year of the mowing of grass; $61.5 \%$ - for the harvest of spike-crops (Table.2).

2. The impact of agrotechnical works on local Cenopopulation of the calf, $M \pm m$

\begin{tabular}{|c|c|c|c|}
\hline \multirow[t]{2}{*}{ Kind of agrotechnical works } & \multicolumn{3}{|c|}{$\begin{array}{l}\text { Number of objects of the animal world, } \\
\text { (pieces) }{ }^{1}\end{array}$} \\
\hline & 2015 & 2016 & 2017 \\
\hline Preparation of green alfalfa mass & $3 /(1)$ & $4 /(1)$ & $2 /-$ \\
\hline Weeding of meadow grasses & $10 /(4)$ & $8 /(2)$ & $7 / 1(2)$ \\
\hline
\end{tabular}




\begin{tabular}{|c|c|c|c|}
\hline Harvesting of spike-crops & $8 / 5$ & $6 / 2$ & $10 / 3$ \\
\hline Together $^{2}$ & $21 / 15$ & $18 / 8$ & $19 / 8$ \\
\hline On the average, of the complex of works & $7,0 \pm 2,08 /$ & $6,0 \pm 1,15 /$ & $6,3 \pm 2,33 /$ \\
& $5,0 \pm 1,73$ & $2,7 \pm 0,67$ & $2,7 \pm 1,45$ \\
\hline
\end{tabular}

1 Birds that: left the area / perished (destroyed eggs);

2 One destroyed eggplant equated to two dead individuals [17]

Following the proposed Requirements, the following results of the conservation of birds were obtained, according to the listed types of works, respectively - 66.7\%; 66.7\%; 75.0\% (2016) and 100\%; 58.3\%; 76.9\% (2017), which up to $40.0 \%$ exceeded the data for 2015 . At that time, the main resourceeconomic indicators were the cost of working hours (machine hours / ha) and fuel and lubricants (diesel fuel ( $\mathrm{kg}$ ) / ha), which determined the total cost of performing agrotechnical works fixed in the research sites by agricultural machines and aggregates, have not undergone any negative changes.

Thus, the proposed Requirements, in comparison with the European practice, where, in addition to the above-mentioned approaches, the terms of harvesting of forages are regulated, the minimum height of mowing of plants, the speed of agricultural machinery, the obligatory equipment of its deterrent devices, etc., are as loyal to the domestic agrarians. They do not restrict the use of conventional technological instruments of plant production; their compliance does not provide for regular financial over-runs, including fuel and lubricants, man-hours and machine hours, and therefore does not reduce the economic efficiency of agricultural production as a whole. Approvals received from the profile issues of the institutions - UkrNII prognostication and testing of equipment and technologies for agricultural production by them. L. Pohoriluy, Ministry of Agrarian Policy of Ukraine, NSC "Institute of Agriculture of NAAN", NUBiP of Ukraine and the State Agency of Forest Resources of Ukraine.

\section{Conclusions}

Compliance with production conditions developed project "Requirements to prevent the death of animals during mechanized farming operations" led to a significant reduction of death and fauna field have resulted in a deterioration in resource-economic indicators of economic activity agribusinesses. A further priority reform the legal framework for the protection faunal complex domestic agricultural landscapes and its adaptation to EU legislation should be better instruments regulate the ways and means of fertilizing the soil and plant protection, 
in accordance with Article 48 "Protection of animals during use of pesticides and agrochemicals" LU " About the animal world ".

\section{Bibliography}

1. Fedyushko M. P. Indykatory stanu asotsiyovanoho ahrobioriznomanittya / M. P. Fedyushko, A. A. Horbatenko, O. H .Hryb // Naukovi dopovidi NUBiPU. - Vyp. 5 (27). - 14 s. [Elektronnyy resurs]. - 2011. - Rezhym dostupu: http://www.nbuv.gov.ua/e-journals/Nd/ 2011_5/11fmp.pdf/

2. Fedyushko M. P. Reaktsiyi indykatornykh vydiv asotsiyovanoho ahrobioriznomanittya na pestytsydne navantazhennya ahrolandshaftiv / M. P. Fedyushko // Naukovi pratsi [Chornomors'koho derzhavnoho universytetu imeni Petra Mohyly]: Ekolohiya: - T. 206. - Vyp. 194. - Mykolayiv : ChDU im. P. Mohyly, 2012. - S. 20-23.

3. Ivanusa A. V. Analiz normatyvno-pravovoho zabezpechennya vedennya myslyvs'koho hospodarstva v Ukrayini / A. V. Ivanusa, V. Z. Kholyavka // Naukovyy visnyk NLTU Ukrayiny. - 2012. - Vyp. 22.1. - S. 165-170. - Rezhym dostupu: http://nbuv.gov.ua/UJRN/nvnltu_2012_22.

4. Novyts'kyy V. P. Upravlinnya myslyvs'kymy resursamy ahrolandshaftiv Ukrayiny ta zarubizhzhya: hospodars'ko-pravovi aspekty / V. P. Novyts'kyy, M. I. Holubyev // Naukovi dopovidi Natsional'noho universytetu bioresursiv i pryrodokorystuvannya Ukrayiny. - 2016. - № 5. - Rezhym dostupu: http://nbuv.gov.ua/UJRN/Nd_2016_5_9. - Zaholovok z ekranu.

5. Bondarenko V.D. Vplyv na faunu okremykh vydiv sil's'kohospodars'kykh robit // Bondarenko V.D. Biotekhniya (Chastyna 2): Navch. posibnyk. - L'viv: IZMN, - 2002. - S. 152-160.

6. Okhorona fauny v ahrolandshaftakh / [Bondarenko V.D., Delehan I.V., Mykhaylyuchenko M.T., Soloviy I.P.]. - L'viv: L'viv. lisotekh. in-t., 1990. - 81 s.

7. Maillard, Jean-François Suffran, Yves Omnès, François - Machinisme agricole et faune sauvage - Faune sauvage, № 291, 2ème trimestre 2011, p, 49-54. 
8. Reitz, F., Gouache, C., Soyez, D. \& Serre, D. 1993. L'effaroucheur électronique à ultrasons «Game-System » : quelle efficacité pour le lièvre ? Bull. Mens. ONC № 184 : 10-15.

9. Zákon Slovenskej republiky zo 16. júna 2009 o pol’ovníctve a o zmene a doplnení niektorých zákonov [Electronic resourse]. - Access mode : http://www.zakonypreludi.sk/zz/2009-274. -Title from screen.

10. Trebovanyya po predotvrashchenyyu hybely obъektov zhyvotnoho myra pry osushchestvlenyy proyzvodstvennukh protsessov, a takzhe pry эkspluatatsyy transportnыkh mahystraley, truboprovodov, lynyy svyazy y Эlektroperedachy, utverzhdenы postanovlenyem Pravytel'stva RF № 997ot 13 avhusta 1996 h. [Elektronnyy resurs]. - Rezhym dostupu : http://pravo.gov.ru/proxy/ips/?docbody=\&nd=102042984. - Zaholovok z ekranu.

11. Rekomendatsyy po okhrane dykykh zhyvotnukh vo vremya mekhanyzyrovannыkh uborochnыkh rabot / Mynysterstvo sel'skoho khozyaystva SSSR, Hlavnoe upravlenye po okhrane pryrodы, zapovednykam, lesnomu y okhotnych'emu khozyaystvam ; razrab. S. H. Manushem. - M. : Kolos, 1981. - 15 s.

12. Aksenov V. D., Svyrydov V. M., Vynokurova Y. A. Puty snyzhenyya stepeny otrytsatel'noho vozdeystvyya traktornoy y druhoy mobyl'noy sel'skokhozyaystvennoy tekhnyky na okruzhayushchuyu sredu (Obzornaya ynformatsyya). — M.: TsNYY-TЭYtraktorsel'khozmash, 1984. — ser. 1, vыр. 5. $-57 \mathrm{~s}$.

13. Zberezhennya bioriznomanittya u zv"yazku iz sil's'kohospodars'koyu diyal'nistyu : metod. rek. / V. A. Solomakha ta in. - K. : Tsentr uchb. l-ry, 2005. 122 s. - Bibliohr.: s. 114- 116.

14. Nesterov Yu.V. Praktychni porady zi zberezhennya bioriznomanittya u sil's'kohospodars'kykh uhiddyakh / Yu.V. Nesterov. - K.: Wetlands International Black Sea Programme, 2005. - 64 c.

15. Metodolohiya naukovykh doslidzhen' : navch. posibnyk / V. Ye. Yurynets'. - L'viv : LNU imeni Ivana Franka, 2011. - 178 s. 
16. Plokhynskyy N.A. Byometryya / N.A. Plokhynskyy. - M. : Yzd-vo MHU, 1970. - $367 \mathrm{~s}$.

17. Poryadok provedennya uporyadkuvannya myslyvs'kykh uhid', zatverdzhenyy Nakazom Derzhavnoho komitetu lisovoho hospodarstva Ukrayiny № 56 vid 21 chervnya 2001 r. [Elektronnyy resurs]. - Rezhym dostupu : http://zakon2.rada.gov.ua/laws/show/z0771-01. - Zaholovok z ekranu. 